\title{
REVISION OF THE GENUS MESOMELAENA (CYPERACEAE)
}

\author{
K. L. WILSON
}

(Accepted for publication 13:2.1981)

\begin{abstract}
Wilson, K. L. (National Herbarium of New South Wales, Royal Botanic Gardens, Sydney, New South Wales, Australia). 1981. Revision of the genus Mesomelaena (Cyperaceae). Telopea 2 (2): 181-195, figs 1-6.-On the basis of morphological and anatomical studies, the genus Mesomelaena is considered to include five species: M. graciliceps (C. B. Clarke) K. L. Wilson, comb. nov., M. preissii Nees, M. pseudostygia (Kükenth.) K. L. Wilson. comb. \& stat. nov., M. stygia (R.Br.) Nees (with two subspecies, ssp. st ygia and ssp. deflexa (Kükenth.) K. L. Wilson, comb. \& stat. nov.) and M. tetragona (R. Br.) Benth. The genus is endemic to the southwest corner of Western Australia.
\end{abstract}

In the family Cyperaceae, the tribe Rhynchosporeae is the only tribe which has many species and genera endemic in Australia. One such genus is Mesomelaena Nees, which is here restricted to a group of five species confined to the south western corner of Western Australia. Kükenthal (1940) treated this genus in his "Vorarbeiten zu einer Monographie der Rhynchosporoideae" but he had inadequate material available to him. Availability of extra specimens and study of the species in the field have shown that improvements can be made to that treatment.

Historically, the species here included in Mesomelaena have been assigned to various genera, starting with the description by Robert Brown (1810) of Chaetospora stygia and C. tetragona (which he placed at the end of Chaetospora in a section Dubii generis).

The next significant step was the description of Mesomelaena by Ness (1846), who included two species in it: $M$. preissii Nees and $M$. stygia $(\mathrm{R}$. Br.) Nees. However, his generic and specific concepts were confused: he left $M$. tetragona as a species of Chaetospora and also described a species Lepidosperma uncinatum which he noted was similar to Mesomelaena but stated that it had the fruit of Lepidosperma and should be placed in that genus. This species of "Lepidosperma" is in fact nothing but Mesomelaena stygia sens. strict. and Nees" " $M$. stygia" is for the most part $M$. pseudostygia, except for var. $\beta$ which is $M$. stygia sens. strict., as suggested by Steudel (1854-1855) and confirmed by Kükenthal (1940).

Steudel (1854-1855) added $M$. bicapitata Steud., which was synonymized by Kükenthal ex descr. with $M$. tetragona (which Steudel listed under Chaetospora, apparently without having seen any specimens of it).

Bentham (1878) broadened the limits of Mesomelaena to include Gymnoschoenus R. Br. and Ptilanthelium Steud, but more recent authors have excluded the latter genera, although not necessarily agreeing on their disposition. Clarke (1908) and Pfeiffer (1927), for example, recognized Gymnoschoenus and Mesomelaena but included Ptilanthelium in Carpha, while Kükenthal $(1939,1940)$, in his "Vorarbeiten", treated all four as distinct genera.

While I agree with Kükenthal's generic disposition of the Australian species (with the exception of $M$. graciliceps, which he placed in Ptilanthelium on the basis of immature specimens), I cannot agree with his specific delimitation within Mesomelaena. He recognized only two species: $M$. tetragona and $M$. stygia, with four varieties in the latter. His argument for including such a varied range of material in $M$. stygia was that the differences were only trivial or related to developmental stage of the specimens (particularly in the shape of the hypogynous scales, which broaden markedly in the lower half with maturity). I would agree that his var. deflexa is based on trivial differences; however, there are well-defined morphological differences (for the main features, see the Key to Species) between the three species I here recognize $(M$. preissii, $M$. pseudostygia and $M$. stygia) corresponding to his varieties under those names. These three closely-related species also differ anatomically (see section on 
Vegetative Anatomy) and for the most part occur over different ranges (see Distribution Maps). $M$. tetragona and $M$. graciliceps are distinctive, less closely-related species.

Within the Rhynchosporeae, the relationships of Mesomelaena are not yet wellknown. Discussion of its relationships properly belongs in a general consideration of the tribe, but some preliminary comment is desirable here. Kükenthal $(1939,1940)$ considered Mesomelaena to be related to Carpha, Gymnoschoenus and Ptilanthelium and devoted considerable space to detailing the differences and similarities between these genera. Koyama (1961) placed Mesomelaena and Gymnoschoenus in his subtribe Cladiinae and Carpha in subtribe Rhynchosporinae. He did not mention Ptilanthelium. Embryological data supports Koyama's disposition of genera rather than that of Kükenthal. Verbelen (1970) examined Carpha and Ptilanthelium in his study of embryo-types in Rhynchosporinae (sensu Koyama, 1961). Vanhecke (1974) was unable to obtain material of Mesomelaena and Gymnoschoenus for his study of Cladiinae, but I have examined the embryos of all species of Mesomelaena and of Gymnoschoenus sphaerocephalus (unpubl. data). Verbelen described the Carpha embryo as a more or less turbinate form of the Fimbristylis-type embryo of Van der Veken (1965). He considered the Ptilanthelium embryo to be quite different: a very elongated turbinate form of the Carex-type embryo of Van der Veken. The embryos of Mesomelaend and Gymnoschoenus are similar to each other. They would be classified as Van der Veken's Schoenus-type, being depressed-obovate as in Lepidosperma and Triscostularia (Vanhecke 1974). This is a very different form from those of Carpha and Ptilanthelium. The correlation of embryo-types with taxonomic limits seems strong, so far as it has been investigated, and certainly in this case it supports the separation of Mesomelaena and Gymnoschoenus from Carpha and Ptilanthelium. At the same time, the gross morphological and anatomical features of Mesomelaena and Gymnoschoenus support their retention as separate genera.

Since these four genera have traditionally been linked (and indeed there is a superficial resemblance of $M$. graciliceps to Ptilanthelium), I present a key that indicates some of the morphological differences between them.

1. Leaves eligulate; inflorescence contracted paniculiform; hypogynous bristles 6; anthers

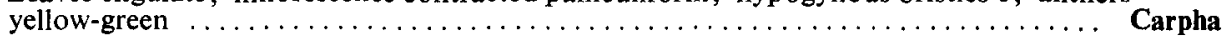
Leaves ligulate; inflorescence a head; hypogynous bristles or scales 1-3; anthers yellow . . . 2

2. Leaves with a ciliate ligule. [Stylebase persistent, glabrous; nut acutely angled, without hypogynous disc.] $\ldots \ldots \ldots \ldots \ldots \ldots \ldots \ldots \ldots \ldots \ldots \ldots \ldots \ldots \ldots \ldots$ Gymnoschoenus Leaves with a membranous or chartaceous ligule 3

3. Stylebase persistent, glabrous; nut acutely angled, without an hypogynous disc; hypogynous scales slender, plumose below, antrorsely scabrous above ..... Ptilanthelium Stylebase deciduous, shortly pubescent; nut obtusely angled or subterete, seated on a hypogynous disc (except $M$. graciliceps); hypogynous scales slender at first, but at maturity very much broadened below and enclosing the nut, glabrous below, very shortly antrorsely scabrous above

Mesomelaena

The following treatment of Mesomelaena is based on examination of specimens in AD, BM, BRI, CANB, E, K, LD, MEL, NSW, P and PERTH, as well as of types sent on loan from $B$. This was supplemented by observation and collection of all species in the field. Only selected specimens are listed in this paper but full lists of specimens examined are available from the author. Distribution maps are based on all specimens that had collection data enabling the locality to be fixed with some degree of certainty. Early collections which appear to extend the range of a species but for which the locality may be doubtful are shown as solid symbols.

\section{Vegetative anatomy}

As in other genera of Cyperaceae, vegetative anatomy provides useful corroborative evidence for distinguishing species. The involucral bract, leaf and culm anatomy of Mesomelaena tetragona, M. stygia (as M. uncinata) and ? M. pseudostygia 
(as $M$. stygia-I have not seen the voucher specimen) were described by Metcalfe (1971), who also reviewed the scanty literature on the subject. I have examined the bract and culm anatomy of all species and also the leaf anatomy of $M$. graciliceps and $M$. tetragona, the only species with well-developed leaf-blades. Cross-sections for the bracts of all species are illustrated in fig. 2, using the shading conventions of Metcalfe (1971).

There is a general similarity amongst the species of Mesomelaena. As noted by Metcalfe, the vascular bundles in the culms are restricted to the central parenchyma (i.e., not 'within the outer band of chlorenchyma as is most usual in the Cyperaceae). As seen in surface view, the cells over the veins tend to be shorter, sometimes markedly so (e.g., in $M$. pseudostygia and $M$. tetragona), and may be thicker-walled than the other epidermal cells (e.g., in M.pseudostygia). Such thick-walled cells may include all the cells overlaying the veins or may occur singly, in pairs or in short rows scattered amongst longer, thinner-walled cells. Metcalfe compared these thickwalled cells with the short cells found in grasses but did not state whether he found them in any other genera of Cyperaceae.

In the following notes on anatomy, generally only features diagonostic for the five species concerned are mentioned in any detail. Other details and terminological definitions may be found in Metcalfe's work cited above. Only those features seen in transverse section (T.S.) are considered here, because such sections are easier to cut than longitudinal sections and also because the cell and tissue arrangements to be observed in T.S. are of more use diagnostically than are those seen in other sections. An additional benefit is that transverse sections are easy to cut with a razor-blade and it is therefore feasible to use such sections as an aid to identification. The sections examined in this study were cut about midway along the length of the culm, leafblade or bract-blade.

\section{T. S. Culm}

Terete in all species except $M$. tetragona, which has a trigonous culm. Epidermal cells enlarged over sclerenchyma strands and girders in all species, except in $M$. tetragona which has smaller cells over the sclerenchyma. Stomates are superficial in all species (fig. 1), but in $M$. preissii are hidden in grooves between the sclerenchyma girders with the epidermal cells at the tops of the grooves produced in papillae which over-arch the grooves (fig. 1). The peripheral sclerenchyma is in the form of strands or girders: both forms present in most species, usually with strands predominating, but only girders found in $M$. preissii. The strands/girders are narrow-triangular except in $M$. graciliceps, in which they are broad-triangular or oblong and are more closely packed than in the other species. The chlorenchymatous band is composed
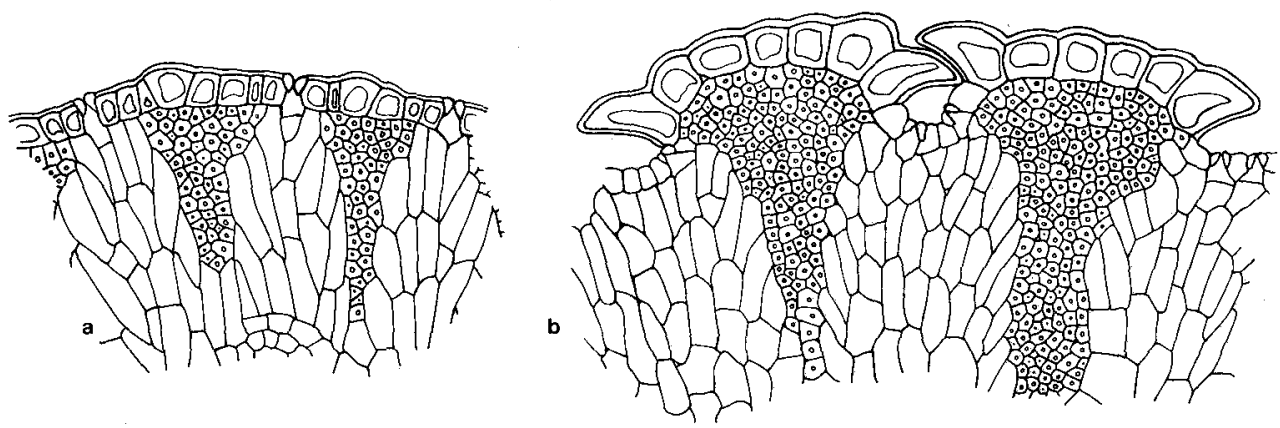

Fig. 1. Detail of T.S. involucral bract $(\times 180)$ : a. Mesomelaena stygia (Wilson 2919); b. $M$. preissii (Wilson 2606). 
of palisade cells, which are often relatively short and broad. The central ground tissue is parenchymatous with the vascular bundles embedded in it, often with slightly smaller parenchymatous cells encircling the bundles and containing some chloroplasts. In $M$. preissii the bundles are generally connected by a network of sclerenchyma, which may be interpreted as equivalent to outgrowths from the sclerenchyma caps that are present on the adaxial poles of the bundles in all other species.

\section{T. S. Involucral bract (fig. 2)}

Outlines varying: flattened-elliptical in $M$. preissii and $M$. stygia, semicircular in $M$. graciliceps, thickly crescentiform in $M$. pseudostygia, and thickly and asymmetrically V-shaped in $M$. tetragona; a central adaxial groove obvious in $M$. tetragona, usually not so in other species. Epidermal cells and stomates as in culms. Peripheral sclerenchyma generally in the form of strands as in culms (girders less common: not found at all in $M$. graciliceps and $M$. pseudostygia, and mixed with strands in $M$. preissii). Strands/girders generally similar in shape to those in culms but even more broadly triangular in $M$. graciliceps, and with only 2-3 palisade cells between adjacent strands in $M$. graciliceps (3-8 in other species). Bract margins (and the edges of the central adaxial groove in $M$. tetragona) marked by broader sclerenchyma strands in all species except $M$. preissi and $M$. stygia. Chlorenchymatous band continuous round the bract, except in $M$. tetragona where it is interrupted at the adaxial groove. Vascular bundles in one irregular row at the inner edge of the chlorenchymatous band, continuous or nearly continuous round the bract, the bundles below the adaxial surface inverted. Central ground tissue parenchymatous with some chloroplasts present in most cells. In $M$. preissii, the bundles are mostly connected by a network of sclerenchyma as in the culm.
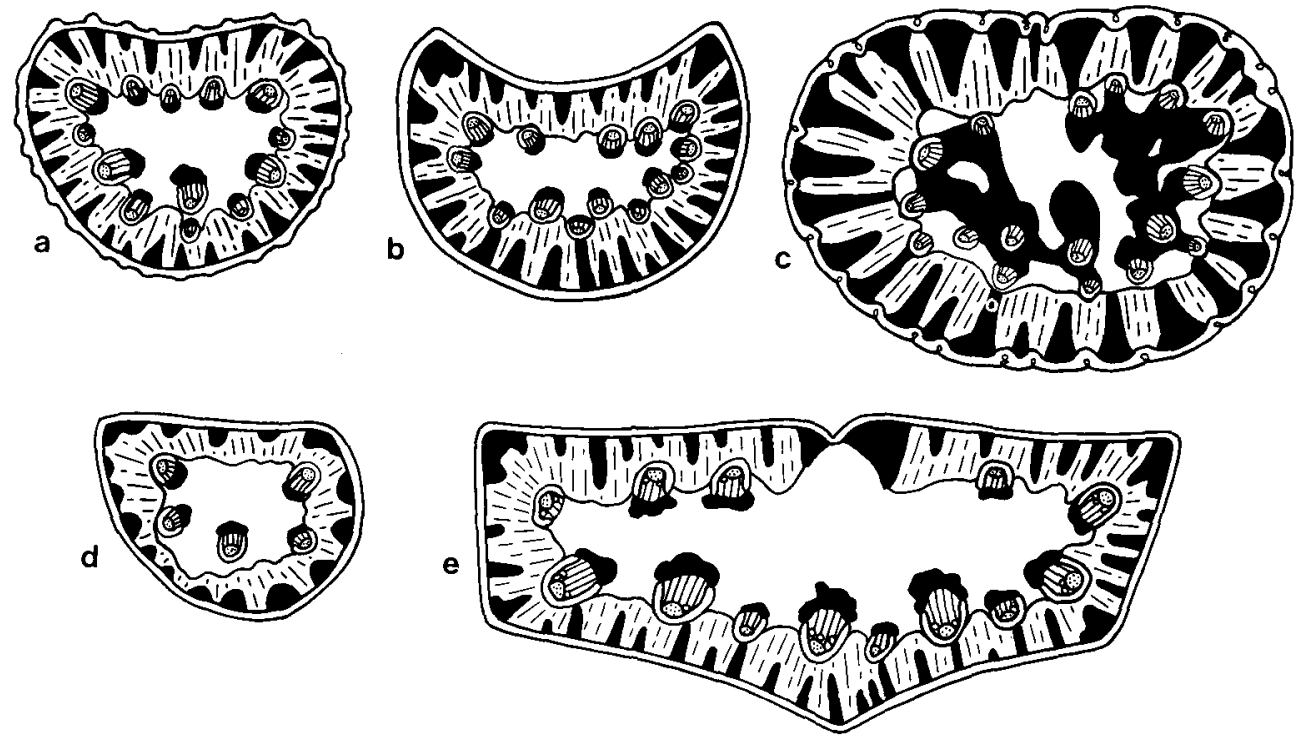

Fig. 2. T.S. involucral bract ( $\times$ 50): a. Mesomelaena stygia (Wilson 2919); b. M. pseudostygia (Wilson 2632); c. M. preissii (Wilson 2606); d. M. graciliceps (Wilson 2957); e. M. tetragona (Tindale 284). Key to shading (fig. 2): solid black-sclerenchyma; dashed-chlorenchyma; white-parenchyma; dotted-phloem; straight lines-xylem. 


\section{T.S. Leaf-blade}

Generally similar to bract in anatomy. Both bracts and leaves tend to flatten towards the apex and hence vary in outline according to the position at which the section is taken.

The bracts and leaf-blades are morphologically equivalent to a pseudo-dorsiventral lamina or an intermediate stage between that and a dorsiventral lamina, as depicted by Metcalfe (1971: fig. 2). This interpretation is indicated by the inverted vascular bundles below the adaxial surface and the continuous (nearly continuous in M. tetragona) chlorenchymatous band.

\section{MESOMELAENA Nees}

in Lehmann, Pl. Preiss. 2: 88 (1846); Bentham, Fl. Austral. 7: 377 (1878), quoad M. stygia \& M. tetragona; Kükenthal, Repert. Spec. Nov. Regni Veg. 48: 49 (1940).-Lectotype species (Koyama 1961): M. stygia (R. Br.) Nees.

Perennial herbs, caespitose, occasionally very shortly rhizomatous. Culms numerous, rigid, terete or compressed, with or without nodes. Leaf-sheaths tightly encircling culm bases, dull or shining, yellow-brown often turning red-brown or grey-brown with age, in some species breaking up with age to form a network of fibres; ligule membranous or chartaceous; leaf-blades reduced, or long, rigid, channelled, pungent-pointed. Inflorescence capitate, hemispherical, globose or narrow fan-shaped, occasionally reduced to a single spikelet, subtended by $1-3$ long rigid involucral bracts with enlarged dark bases that envelop the inflorescence at least when immature. Spikelets oblong-lanceolate, compressed, sessile, usually producing only one nut, but a second flower usually apparently bisexual; glumes 5-10 (the lowest 3-8 empty), distichous, carinate, oblong-lanceolate, brown to black with the bases paler, produced in a straight to excurved awn often as long as the body of the glume. Rachilla short, straight. Hypogynous scales 3, similar, brown to black above, paler below, finely antrorsely scabrous above, at first slender, at maturity very much broadened at the base and loosely enclosing the nut, abruptly acuminate and twisted above. Stamens 3; anthers linear, yellow, with the connective produced in a long subulate appendage. Style long, 3-fid, antrorsely scabrous, not persistent on the nut. Nut dry, indehiscent, glabrous, ovate or oblong-ovate, trigonous with very obtuse angles, apex obtuse, base broad; in most species seated on a thickened, cupshaped gynophore with or without a spreading, 3-lobed disc at the top.

Distribution: The five species are found in the southwest of Western Australia, from the Murchison River to near Coolgardie and to Israelite Bay; generally on sandy soils in various heath formations. One species, $M$. preissii, is found on the more Inland lateritic sandplains while the rest are more or less restricted to coastal sandplains, with extensions into the Darling and Stirling Ranges. $M$. graciliceps usually grows in low-lying and at least seasonally swampy areas, while the other species are found in drier habitats.

NoTEs: Further generic and specific literature citations may be found in Kükenthal (1940).

In using the key and descriptions the following points should be noted. Colour differences in the culms are less obvious in dried specimens than in the living plants. Measurements of anther length do not include the apical appendage, which is readily broken off. On the other hand, measurements of nut length do include the gynophore. All species may occasionally produce much longer nuts than the typical ones illustrated. 
Key to species of Mesomelaena

1. Culms 1-noded; leaf-blades $20-55 \mathrm{~cm}$ long; leaf-sheaths compressed; $2-3$ of the involucral bracts $10-30 \mathrm{~cm}$ long, more than three times longer than the inflorescence

5. M. tetragona

Culms not noded; leaf-blades no more than $15 \mathrm{~cm}$ long; sheaths not compressed; 1-2

of the involucral bracts $2-8 \mathrm{~cm}$ long, at least twice as long as the inflorescence $\ldots \ldots \ldots \ldots \ldots$.

2. Two of the involucral bracts subequal, longer than the inflorescence; ligule brown, narrow, chartaceous, occasionally with a narrow membranous margin .. 3. M. pseudostygia One involucral bract longer than the inflorescence, with a second bract no longer than the inflorescence; ligule white-membranous, to $1 \frac{1}{2} \mathrm{~cm}$ long $\ldots \ldots \ldots \ldots \ldots \ldots \ldots \ldots, \ldots \ldots$

3. Leaf-sheaths yellow-brown, very shiny; culms markedly ridged

4. M. stygia Leaf-sheaths red-brown to grey-brown with age, dull or only slightly shiny; culms not

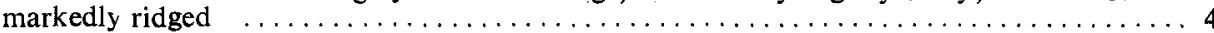

4. Culms grey-green; inflorescence a hemispherical or globose head of numerous spikelets; nut $2-2 \frac{1}{2} \mathrm{~mm}$ long, seated on an hypogynous disc .............. 2. preissii Culms yellow-green; inflorescence a narrowly elliptic head of $1-5$ spikelets; nut $5-8 \mathrm{~mm}$

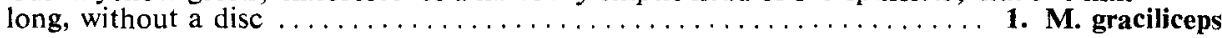

\section{Mesomelaena graciliceps (C. B. Clarke) K. L. Wilson, comb. nov.}

Basionym: Carpha graciliceps C. B. Clarke, Bot. Jahrb. Syst. 35: 81 (1904),-Ptilanthelium graciliceps (C. B. Clarke) Kükenth., Repert. Spec. Nov. Regni Veg. 47: 216 (1939), as 'gracilipes'.

HolotyPE: pr. fretum King George Sound in arenosis subhumosis humidis, Diels 2694, iii.1901 (K).

Culms erect at first, often becoming decumbent with age, terete, compressed or sulcate, smooth, without nodes, light yellow-green, $20-60 \mathrm{~cm}$ high, $0.5-1.3 \mathrm{~mm}$ diam. Leaf-sheaths red-brown turning grey-brown with age, 土 shining, remaining intact; ligule membranous, to $1.5 \mathrm{~cm}$ long; leaf-blades often reduced or occasionally to $15 \mathrm{~cm}$ long. Inflorescence narrowly elliptic $14-20 \mathrm{~mm}$ long, c. $3 \mathrm{~mm}$ diam., with 1-5 spikelets. Involucral bracts: 1 longer than the inflorescence, $2.5-5.5 \mathrm{~cm}$ long; a second bract opposed to the first, with a short blade to $5 \mathrm{~mm}$ long; both bracts with broadened bases with narrow membranous margins which envelop the inflorescence except at maturity. Spikelets 12-18 mm long; glumes 4-6, with a short, straight awn. Anthers c. $5 \mathrm{~mm}$ long, with an appendage c. $1.5 \mathrm{~mm}$ long. Nut $5.0-8.0 \mathrm{~mm}$ long, $2.0-2.2 \mathrm{~mm}$ diam., whitish or brown or grey with brown-black spots, obovateoblong to long-elliptical; gynophore united with the base of the nut, yellowish, without disc. Fig. 3.

Distribution: Widespread, but inconspicuous and therefore easily overlooked by collectors, in low-lying, at least seasonally swampy, areas of low heath on the coastal sandplains from just north of Perth to Duke of Orleans Bay and inland to the Stirling Range. The apparent disjunctions between Perth and the southwest corner of the State and the Scott River Plain and Albany may reflect lack of collection or perhaps lack or destruction of suitable habitats. This species is found in wetter situations than the other species in the genus.

SPECIMENS Examined: 24.

Selected SPeCimens: Darling*: Drummond: $4 \frac{1}{2}$ miles $[7 \mathrm{~km}] \mathrm{NW}$ of Gnangara Forestry H. Q., Chadwick 1582, 4.1964 (PERTH): Gales Road, Ambergate, Wilson 3056, 10.1979 (NSW, P, PERTH). Dale: Darlington, Royce 1466, 4.1947 (PERTH); $50 \mathrm{~km}$ SSE. of Perth, Albany Highway, Newbey 4976, 6.1976 (NSW, PERTH). Warren: Witchcliffe, Royce 2437, 10.1948 (PERTH); McGregor Road, $8 \mathrm{~km}$ S. of Brockman Highway, Scott R. Plain, Wilson 3028, 10.1979 (NSW). Menzies: Cowaramup, Royce 2820, 10.1948 (PERTH); Rosa Brook, Royce 2798, 10.1948 (PERTH); $3 \mathrm{~km}$ E. of Blackwood R. on Brockman Highway, E. of Alexandra Bridge,

\footnotetext{
* The phytogeographic districts (e.g., Darling) and subdistricts (e.g., Drummond) used are those
} proposed by Beard (1980). 


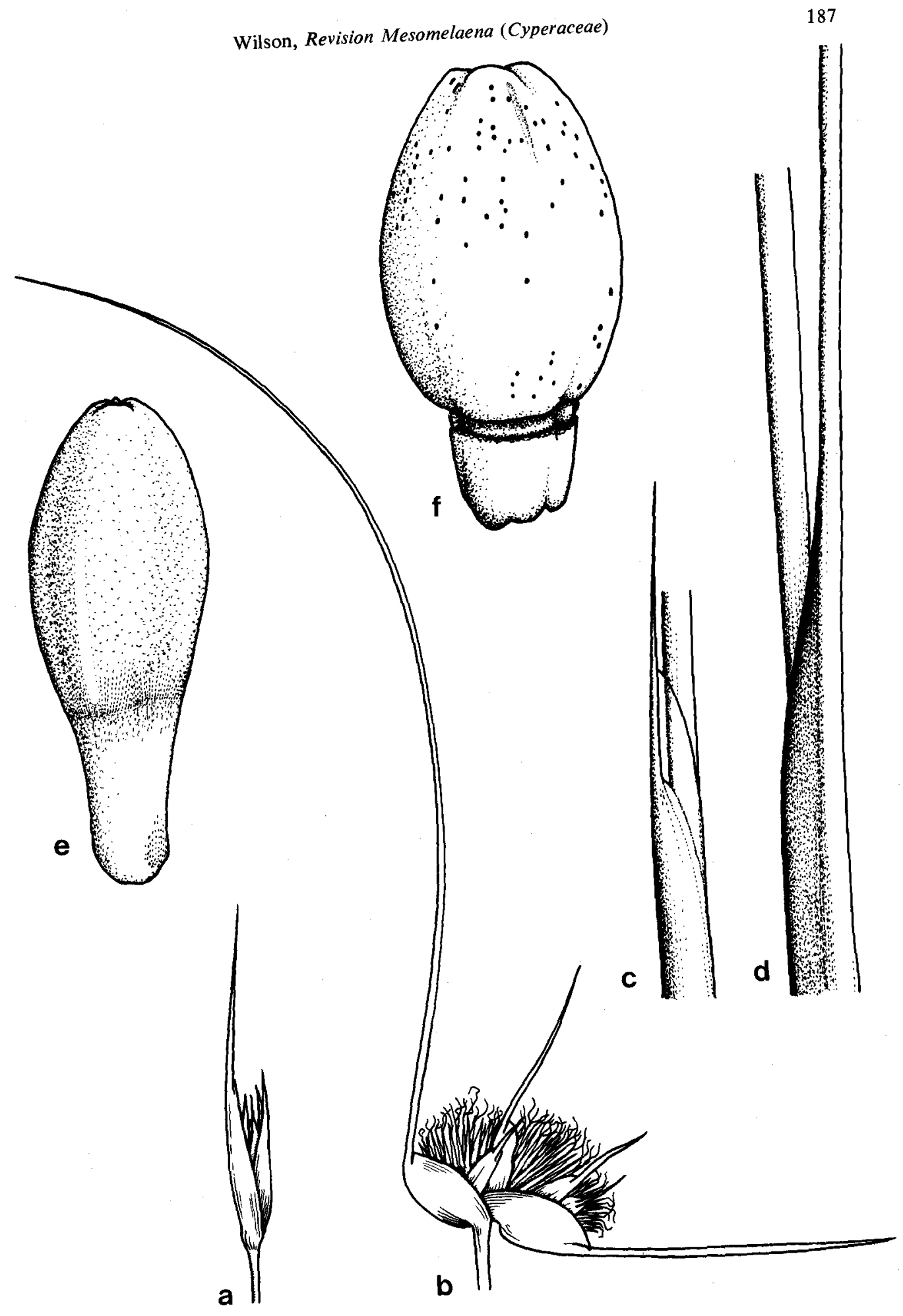
Fig. 3. Inflorescence ( $\times$ 1): a. Mesomelaena graciliceps; b. $M$. tetragona. Leaf-sheath margins (× 3): c. M. graciliceps; d. M. tetragona. Nut (X 10 . 18 (M. tetragona)). tetragona. (Drawn from Wilson 2957 (M. graciliceps) and Wilson 2918 (M. tetragona)) 
Wilson 3050, 10.1979 (NSW, PERTH, PH); 3 miles [5 km] S. of Mt Barker, Royce 4235, 7.1952 (PERTH); Narrikup, on road to Albany, Melville 4388 \& Royce, 7.1953 (MEL, NSW, PERTH); $12 \frac{1}{2} \mathrm{~km}$ N. of Albany on Chester Pass Road, Wilson 2957, 10.1979 (BRI, CHR, L, NSW, PERTH). Eyre: 2 km SW. of Whartons Campsite, Duke of Orleans Bay, Wilson 2869, 10.1979 (AD, CANB, NSW, P); $1 \mathrm{~km}$ W. of Rossiter Bay on road to Lucky Bay, Cape Le Grand National Park, Wilson 2850, 10.1979 (CHR, K, NSW, PERTH, PRE); East Mt Barren, Fitzgerald R. National Park, Wilson 2888, 10.1979 (K, NSW); below Bluff Knoll, Stirling Range National Park, Wilson 2983, 10.1979 (MEL, NSW); $18 \mathrm{~km}$ W. of Bremer Bay, Newbey 4073, 3.1974 (NSW, PERTH), Wilson 2924, 10.1979 (BRI, L, NSW, NY, PERTH, US); $5 \mathrm{~km} \mathrm{NW.} \mathrm{of} \mathrm{Cape} \mathrm{Riche} \mathrm{on}$ Wellstead road, Wilson 2942, 10.1979 (NSW, TNS).

2. Mesomelaena preissii Nees in Lehmann, Pl. Preiss. 2: $88(1846)$. $-M$. stygia var. preissii (Nees) Kükenth., Repert. Spec. Nov. Regni Veg. 48 : 54 (1940).

LECTOTYPE (here designated): in paludosis haud longe a Halfwayhouse, Darlings-range, Preiss 1791, ix.1839 (LD). IsOLeCtOTYPES: BM, MEL (2 sheets), P.

Chaetospora stygia forma: Boeck., Linnaea 38: 295 (1874).

Preiss 1791 was the only specimen cited by Nees and therefore is the type. The holotype sheet would have been in Nees' own herbarium which was incorporated in B and subsequently destroyed during the Second World War. What seems to be regarded as the original set of Preiss specimens (from Lehmann's herbarium) was sold by Lehmann's widow to Agardh in Lund (Nordenstam 1980), although it is possible that this set is not quite complete (B. Nordenstam and P. Lassen, pers. comm.). I have chosen the sheet of Preiss 1791 (annotated by Nees) in LD as the lectotype.

Culms erect, terete, without nodes, grey-green, 20-60 cm high, c. $1 \mathrm{~mm}$ diam. Leaf-sheaths pink-brown turning grey-brown with age, usually not shining, breaking up with age to form a network of fibres round the base of the culms; ligule obvious, white-membranous, to $1.5 \mathrm{~cm}$ long; leaf-blades reduced, to $3.5 \mathrm{~cm}$ long. Inflorescence globose or hemispherical, 9-14 $\mathrm{mm}$ diam. Involucral bracts: 1 longer than the inflorescence, 3-8 cm long, with a second bract opposed with a short awn; both bracts with broad hyaline margins. Spikelets $8-10 \mathrm{~mm}$ long; glumes 6-7, with an excurved awn. Anthers $2.5-4.0 \mathrm{~mm}$ long, with an appendage $1.0-1.7 \mathrm{~mm}$ long. Nut 2.0-2.5 mm long, 1.2-1.5 mm diam., whitish, short-ovate; gynophore yellowish with a spreading or reduced disc. Fig. 4.

Distribution: Widespread in the drier inland regions of southwestern Western Australia, approaching the coast most closely in the Badgingarra area; in scrub heaths on lateritic saridplains. Fig. 6.

SPeCimens Examined: 36.

Selected Specimens: Irwin: between Naraling and Yuna, Blackall 4747, 9.1940 (PERTH); c. 18-20 km WNW. of Arrino, Hnatiuk 800013,800018, 7.1980 (PERTH); $14 \mathrm{~km} \mathrm{SW}$. of Three Springs on Eneabba road, Wilson $2681,10.1979$ (NSW, P); near Marchagee, Aplin $78,9.1958$ (PERTH); Watheroo National Park, W. of Watheroo, Royce 9691, 10.1971 (PERTH); Badgingarra, 78 miles [125 km] NNW. of Gingin by road, Aplin \& Coveny $3170,9.1970$ (BRI, K, NSW, P, PERTH); $11 \mathrm{~km}$ SE. of Badgingarra on Moora road, Wilson 2713, 10.1979 (NSW). Avon: c. $25 \mathrm{~km}$ NNW. of Wongan Hills township, Wilson 2613, 9.1979 (CHR, K, NSW, P, PERTH, TNS); $7 \mathrm{~km} \mathrm{~N}$. of Dowerin on Cadoux road, Wilson 2588, 9.1979 (BRI, L, NSW); $4 \mathrm{~km} \mathrm{W.} \mathrm{of}$ Tammin Railway Station, Coveny 8296 \& Habersley, 9.1976 (K, NSW, P, PERTH); 4 miles [6 km] NW. of Cunderdin, Aplin 605, 2.1960 (PERTH); Muntadgin, Stone \& Bailey 429, 8.1947 (PERTH); c. $3 \mathrm{~km} \mathrm{NW}$. of Bullaring on Pingelly road, Wilson 2606, 9.1979 (CHR, NSW); 2 miles [3 km] N. of Dumbleyung on road to Kukerin, Tindale 157, 3. 1970 (BRI, NSW, PERTH), Darling: Dale: Toodyay, Oldfield 221 (MEL); Wooroloo, Koch 1729 p.p., 8.1907 (K); also lectotype of $M$. preissii. Roe: $33 \mathrm{~km}$ WSW. of Round Top Hill, c. $153 \mathrm{~km}$ W. of Norseman, Newbey 6273, 11.1979 (NSW, PERTH); $30 \mathrm{~km}$ W. of Lake Grace township, Wilson 3413, 9.1964 (AD, NSW, PERTH); c. $40 \mathrm{~km}$ E. of Lake King township, Wilson 3214, 9.1964 (AD); $19 \mathrm{~km} \mathrm{~N}$. of Pingrup on Lake Grace road, Wilson 277l, 10.1979 (BRI, L, NSW, PERTH, US); $19 \mathrm{~km} \mathrm{S.} \mathrm{of}$ Lake King on Ravensthorpe road, Wilson $2786,10.1979$ (K, NSW); $10 \mathrm{~km} \mathrm{~N}$. of Nyabing ("Niabing"), Koch NI7, 1.1978 (PERTH). Coolgardie: 56.7 miles [91 km] from Southern Cross towards Coolgardie, along Great Eastern Highway, Canning 2493, 9.1968 (NSW). 

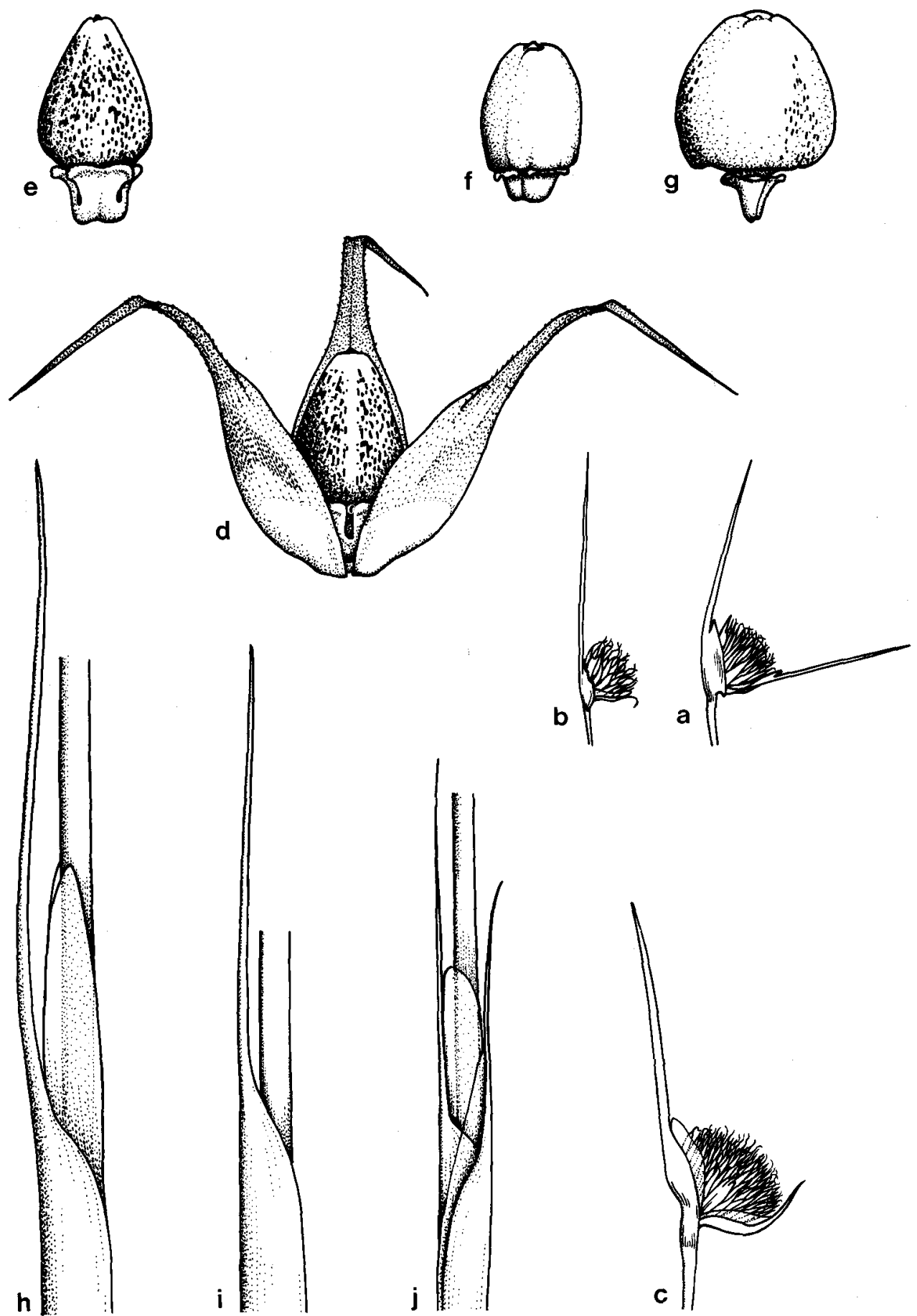

Fig. 4. a-c: Inflorescences $(\times 1)$ : a. Mesomelaena pseudostygia; b. M. stygia; c. M. preissii. d. Nut and surrounding hypogynous scales (spread apart for the illustration) of $M$. stygia $(\times 10)$. e-g: Nuts $(\times 10)$ : e. M. stygia; f. M. preissii; g. $M$. pseudostygia. h-j: Leaf-sheath margins (× 3): h. M. preissii; i. M. pseudostygia; j. M. stygia. (Drawn from Wilson 2583 (M. preissii), Aplin \& Coveny 3119 (M. pseudostygia) and Wilson 2919 (M. stygia)). 


\section{Mesomelaena pseudostygia (Kükenth.) $K$. L. Wilson, comb. et stat, nov.}

BAsionym: $M$. stygia var. pseudostygia Kükenth., Repert. Spec. Nov. Regni Veg. 48: 53 (1940). LectotyPe (here designated): Mogumber, Meebold 6663, xii.1929 (B).

M. stygia auct. non (R.Br.) Nees: C. B. Clarke, Illustr. Cyper.: tab. 94 (1909).

Chaetospora stygia Boeck., Linnaea 38: 294 (1874), p.p. max. non R. Br.

Culms erect, terete, smooth or faintly scaberulous, without nodes, light yellowgreen, 25-60 cm high, 0.7-1.5 mm diam. Leaf-sheaths pink-brown turning grey-brown with age, not shining, breaking up with age to form a network of fibres round the base of the culms; ligule a narrow, chartaceous red-brown band (occasionally to $5 \mathrm{~mm}$ long in younger leaves), occasionally with a narrow membranous border; leaf-blades reduced, to $2 \mathrm{~cm}$ long. Inflorescence globose to hemispherical, $7-10 \mathrm{~mm}$ diam. Involucral bracts: 2 longer than the inflorescence, with 1 erect and the other at c. $90^{\circ}$ to the culm, both $2-5.5 \mathrm{~cm}$ long, subequal with narrow membranous margin to bases. Spikelets $8-10 \mathrm{~mm}$ long; glumes 6-7, with a straight to recurved awn. Anthers $2.0-3.0 \mathrm{~mm}$ long with an appendage $1.2-1.8 \mathrm{~mm}$ long. Nut 3.0-4.0 mm long, $1.5-1.8 \mathrm{~mm}$ diam., whitish, ovate; gynophore yellowish, with a small, erect or spreading disc. Fig. 4.

Distribution: Widespread in the coastal sandplain heaths and scrub heaths from just south of Perth north to the Murchison River and possibly to Shark Bay (one old collection labelled thus). Fig. 6.

SPECIMENS EXAMINed: 45.

Selected Specimens: Irwin: Shark Bay, Mueller, 10.1877 (MEL); $6 \mathrm{~km}$ E. of Kalbarri on Meanarra Drive, Wilson 2632, 9.1979 (BRI, L, NSW); $16 \mathrm{~km} \mathrm{~N}$. of Northampton on Ajana road, Wilson 2637, 9.1979 (K, NSW, P, PERTH); 30 miles [48 km] E. of Geraldton, Long 44, 4.1960 (PERTH); 3 miles [5 km] W. of Casuarina, Hnatiuk 760313, 8.1976 (PERTH); c. 18-20 km WNW. of Arrino, Hnatiuk 800014, 7.1980 (PERTH); Western Titanium Leases, $8 \mathrm{~km} \mathrm{~S}$. of Eneabba, Griffin 649, 10.1977 (PERTH); $1 \mathrm{~km} \mathrm{W.} \mathrm{of} \mathrm{Brand} \mathrm{Highway} \mathrm{along} \mathrm{Green} \mathrm{Head} \mathrm{road,}$ Wilson 2694, 10.1979 (NSW, PERTH). Avon: Lectotype of M. pseudostygia. Darling: Drummond: $15 \mathrm{~km}$ N. of Cataby Creek, Hnatiuk $760098,8.1976$ (PERTH); 31 miles [50 km] NNW, of Gingin, Aplin \& Coveny 3119, 9.1970 (BRI, K, NSW, PERTH); Yanchep National Park, James 118, 11.1963 (PERTH); Mullaloo Beach road, W. of Wanneroo, Aplin 929, 8.1961 (PERTH); Kewdale, Coveny 8202, 9.1976 (NSW, P, PERTH); Cannington, near Perth, Blake 17982, 8.1947 (BRI, NSW, PERTH); Perth, Preiss 1760, 4.1839 (BM, K, LD, MEL, P), Preiss 1761, 4.1839 (BM, LD, MEL, P); Subiaco, Morrison, 11.1909 (BM, K); Lower Helena Valley, Seabrook 59/512, 7-12.1977 (PERTH); Freemantle [sic], Preiss 1786, 12.1838 (LD, MEL, P); 5 miles [8 km] NNE. of Kwinana, Salasoo 3998, 9.1970 (NSW); Melville, 8 miles [13 km] S. of Perth, Turvey NSW 91160, 8.1965 (NSW); Pinjarra, Gardner, 9.1935 (PERTH).

4. Mesomelaena stygia (R.Br.) Nees in Lehmann, Pl. Preiss. 2: 89 (1846), quoad var. $\beta$ solum; Bentham, Fl. Austral. 7: 378 (1878) p.p.; Kükenthal, Repert. Spec. Nov. Regni Veg. 48: 52 (1940) p.p.-Chaetospora stygia R. Br., Prodr.: 233 (1810); Boeck., Linnaea 38: 294 (1874) p.p. min.

Holotype: King George Sound, Brown (BM). IsoTyPeS: K, MEL.

Culms erect, terete, \pm smooth, without nodes, light yellow-green, $10-50 \mathrm{~cm}$ high, 0.5-1.5 mm diam. Leaf-sheaths yellow-brown, shining, remaining intact; ligule membranous, to $5 \mathrm{~mm}$ long; leaf-blades reduced, to $3 \mathrm{~cm}$ long. Inflorescence hemispherical, $7-12 \mathrm{~mm}$ diam., occasionally reduced to 1 spikelet. Involucral bracts: 1 exceeding the inflorescence, erect or occasionally bent at right-angles to the culm, $2-5.5 \mathrm{~cm}$ long, the broad base with a hyaline margin; a second bract with broad base and short awn opposite the first bract. Spikelets 5.5-7 mm long; glumes 5-10, with an excurved or recurved awn. Anthers c. $3 \mathrm{~mm}$ long, with an apical appendage 1.0-1.5 mm long. Nut 2.5-3.5 mm long 1.1-1.7 mm diam., whitish, ovate to ovate-oblong; gynophore yellowish, with very small disc or disc absent. Fig. 4.

Distribution: Widespread in the southern coastal sandplain heaths from near Perth to Israelite Bay (not common from Perth to Albany), extending inland to the Stirling Range and north of Ravensthorpe towards Lake King, and with an apparently disjunct occurrence in the Eneabba area. Fig. 6. 


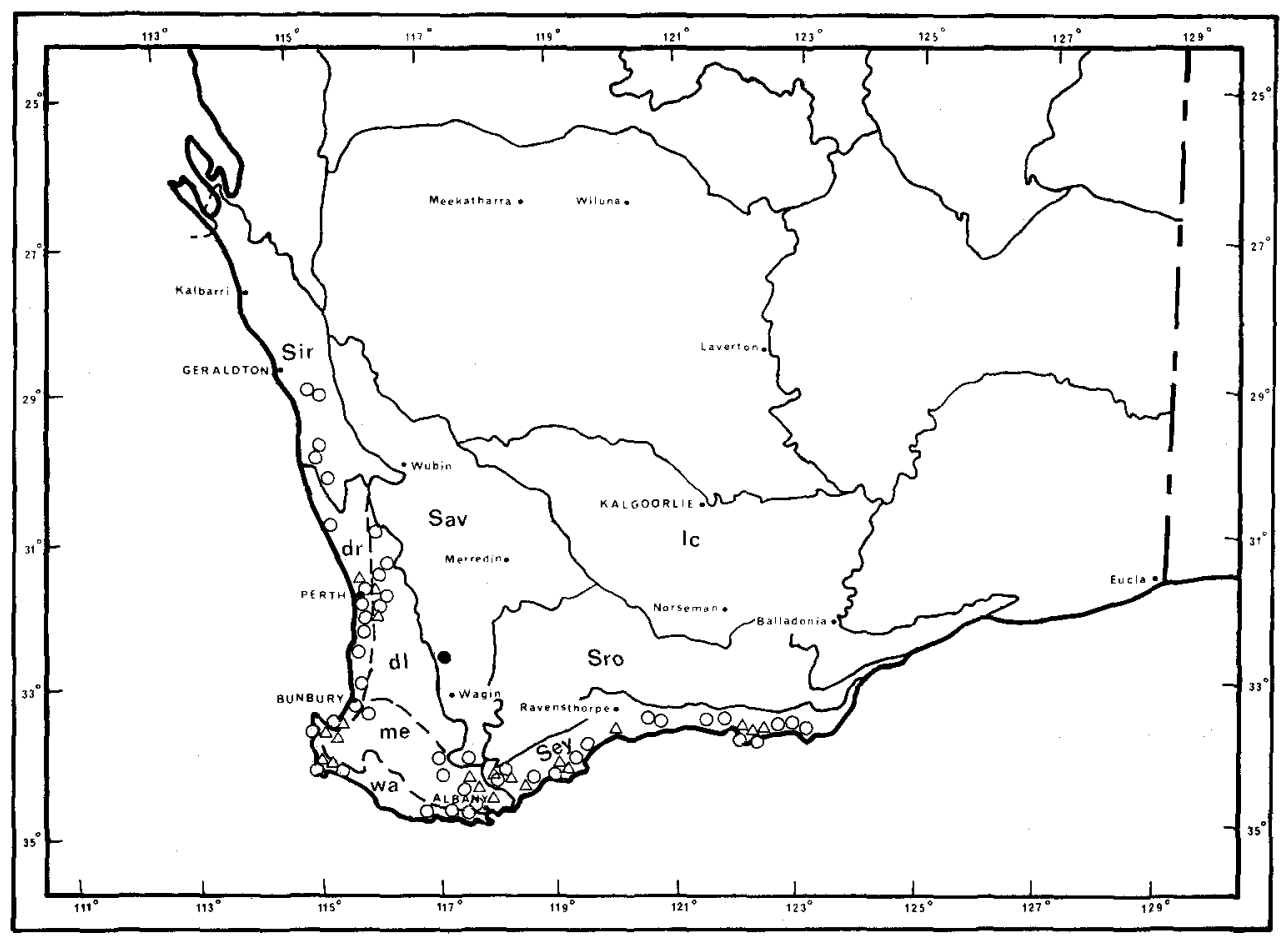

Fig. 5. Distribution in Wèstern Australia of Mesomelaena graciliceps $(\triangle)$ and M. tetragona (0). A solid symbol indicates a doubtful locality for a specimen.

Abbreviations for botanical districts and subdistricts, taken from Beard (1980):

Southwestern Interzone: Ic $=$ Coolgardie.

South-west Province: Sav $=$ Avon; (S) $\mathrm{dr}=$ Darling subdistrict Drummond; $(\mathrm{S}) \mathrm{dl}=$ Darling subdistrict Dale; $(\mathbf{S}) \mathrm{me}=$ Darling subdistrict Menzies; $(\mathrm{S})$ wa $=$ Darling subdistrict Warren; Sey $=$ Eyre; Sir $=$ Irwin; Sro $=$ Roe.

In the southern part of its range, the species is fairly homogeneous. This is the form described by Robert Brown as Chaetospora stygia and here called $M$. stygia ssp. stygia. A different form is found in the Arrino-Eneabba area and this was segregated as var. deflexa by Kükenthal (ssp. deflexa in this treatment). The three specimens known of ssp. deflexa are very similar to each other and have a dramatically different facies from ssp. stygia due to the longest involucral bract being not erect but deflexed at an angle of at least $90^{\circ}$ from the vertical. They are relatively slender plants compared to southern specimens but do not differ significantly in other characters (including vegetative anatomy) from ssp. stygia. In recognition of the geographic isolation and the distinctive appearance of these plants due to the deflexed bract, they are distinguished here as ssp. deflexa. This infraspecific variation between the two major coastal sandplain regions (Moore River to Shark Bay in the north and Stirling Range to Israelite Bay in the south) is found in other species such as Eucalyptus tetragona, as reported by George et al. (1979). 


\section{Key to Subspecies}

1. Lowest involucral bract erect; culms $0.7-1.5 \mathrm{~mm}$ diameter; nut $3.0-3.5 \mathrm{~mm}$ long

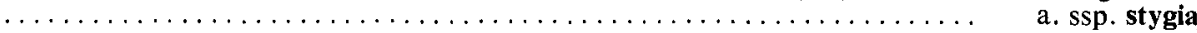

1.* Lowest involucral bract deflexed at about $90^{\circ}$ to the culm; culms $0.5-0.7 \mathrm{~mm}$ diameter; nut c. $2.5 \mathrm{~mm}$ long

b. ssp. deflexa

\section{a. ssp. stygia}

Lepidosperma uncinatum Nees in Lehmann, Pl. Preiss. 2: 93 (1846). -Mesomelaena uncinata (Nees) C. B. Clarke, Kew Bull. Add. Ser. 8: 48, 127 (1908). - -HoLotYPE: in regionibus interioribus Australiae meridionali-occidentalis, Preiss 1772, xi.1840 (B-probably destroyed). ISOTYPES: MEL, $P$.

Diagnostic characters as in the key.

Distribution: throughout the southern part of the range of the species.

SPECIMENS EXAMINED: 69.

Selected SPecimens: Darling: Drummond: North Dandalup, Blake 18047, 8.1947 (BRI, MEL, NSW, PERTH); Boyanup, Royce 2664, 9.1948 (BRI, PERTH); Ambergate, S. of Busselton, Royce 2893,10.1948 (BRI, PERTH); in districtu Sussex, Preiss 1796, 12.1839 (BM, LD, MEL, P.)' Dale: William River, K.G.S. road, Oldfield 759 (MEL); sandplain near the William River, Oldfield (K, MEL). Menzies: Blackwood River, Miss Hester, 1876 (MEL); Tenterden, Morrison, 9.1902 (K); Forest Hill, Muir (MEL); Albany, Andrews, 12.1902 (BM, K); holotype M. stygia. Avon: 3-4 miles [5-6 km] NW. of Cranbrook, Green 1735, 10.1957 (PERTH). Eyre: $46 \mathrm{~km} \mathrm{E}$. of Ravensthorpe on Esperance road, Wilson 2809, 10.1979 (K, NSW); Israelite Bay, Willis, 11.1950 (K, MEL); near Howick Hill, Eichler 19828, 9.1968 (AD, PERTH); Cape Arid National Park, E. of Esperance, Royce 9940,12.1972 (PERTH); Thistle Cove, Cape Le Grand National Park, Wilson 2844, 10.1979 (L, NSW); $17 \mathrm{~km} \mathrm{E}$. of Fitzgerald R. crossing on RavensthorpeJerramungup road, Wilson 2897, 10.1979 (NSW); East Mt Barren, Fitzgerald R. National Park, Wilson 2887, 10.1979 (NSW, P); 11 miles [18 km] SE. of Ongerup, Newbey 3722, 8.1973 (PERTH); Boxwood Hills, at turn-off to Bremer Bay, Wilson 2929, 10.1979 (K, NSW, P, PERTH, TNS); $\frac{1}{2} \mathrm{~km}$ from Chester Pass Road on Stirling Range Drive, Wilson 2993, 10.1979 (NSW, PERTH, TNS, US); $5 \mathrm{~km} \mathrm{~N}$. of Kamballup on Chester Pass Road, Wilson 2974, 10.1979 (NSW); Warriup Hill, E. of Albany, Gardner, 7.1940 (PERTH). Roe: Frank Hann National Park, Monk 259, 8.1978 (PERTH); $19 \mathrm{~km} \mathrm{~S}$. of Lake King on Ravensthorpe road, Wilson 2787, 10.1979 (BRI, NSW); c. 2 km W. of Mt Ragged, Kuchel 1604, 1606, 9.1964 (AD); 29 miles [45 km] N. of Esperance, Cleland, 9.1950 (Ad): $8 \mathrm{~km} \mathrm{~N}$. of Needilup, Newby 4226, 6.1974 (NSW, PERTH); c. $20 \mathrm{~km}$ W. of Ongerup, Whibley 5278, 11.1974 (AD).

\section{b. ssp. deflexa (Kükenth.) K. L. Wilson, comb. et stat. nov.} (1940).

Basionym: Mesomelaena stygia var. deflexa Kükenth., Repert. Spec. Nov. Regni Veg. $48: 53$

HOLOTYPE: between the Arrowsmith and Irwin Rivers, Mueller, xi.1877 (B).

The type of var. deflexa was cited by Kükenthal as in herb. Phytol. Mus. Melbourne' (=MEL) but, as in other cases of Kükenthal's types, I have found the specimen not in MEL but in B.

Diagnostic characters as in the key.

Distribution: Known only from the Arrino-Eneabba region.

SPeCimens Examined: Irwin: Holotype of ssp. deflexa; c. 18-20 km WNW. of Arrino, Hnatiuk 800012, 7.1980 (NSW, PERTH); Western Titanium Leases, $8 \mathrm{~km}$ S. of Eneabba, Griffin $651,10.1976$ (PERTH).

5. Mesomelaena tetragona (R. Br.) Benth., Fl. Austral. 7: 379 (1878); Kükenthal Repert. Spec. Nov. Regni Veg. 48: 55 (1940). -Chaetospora tetragona R. Br., Prodr.: 233 (1810); Nees in Lehmann, Pl. Preiss. 2: 86 (1846).

Holotype: King George Sound, Brown (BM). IsoTyPE: E.

Mesomelaena bicapitata Steud., Synopsis Pl. Glum. 2: 163 (1855), ex. descr.-HoLotyPE: "Port. Georg. N. Holl." (n.v.).

Although I saw several sheets in P of this species, I found none labelled as coming from Steudel's herbarium or as being $M$. bicapitata. 


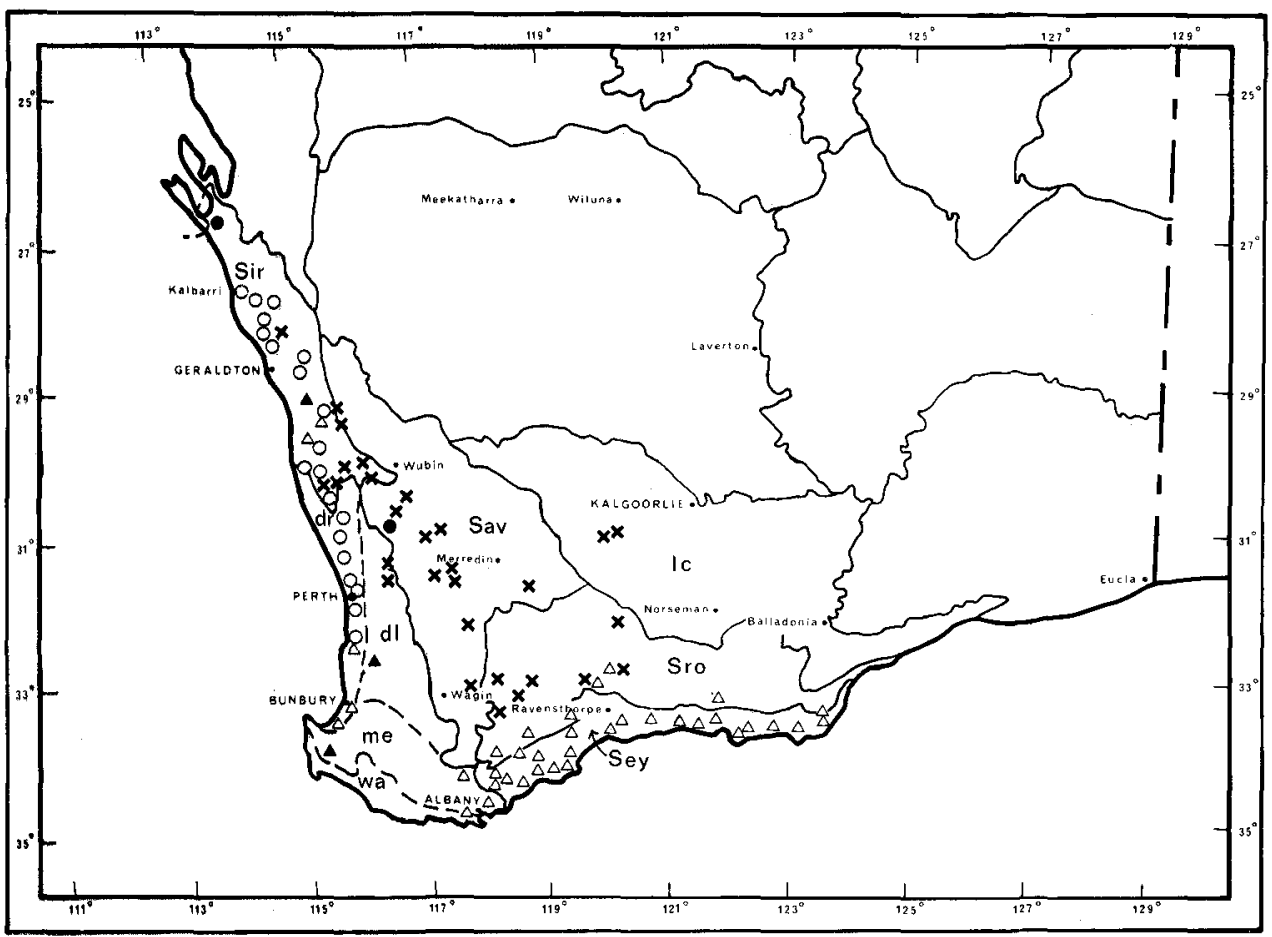

Fig. 6. Distribution in Western Australia of Mesomelaena preissii $(\times), M$. pseudostygia $(0)$ and M. stygia $(\triangle)$ [ssp. deflexa in the Eneabba area and ssp. stygia $\mathrm{S}$. of Perth and along the southern coast]. A solid symbol indicates a doubtful locality for a specimen.

Culms erect, trigonous, \pm smooth or scabrous below the inflorescence, 1-noded, yellow-green, $30-70 \mathrm{~cm}$ high, c. $2.5 \mathrm{~mm}$ diam. Leaf-sheaths compressed laterally, pink- or yellow-brown becoming black-brown at maturity, shining, remaining intact; ligule a narrow, shining, brown-black chartaceous band; leaf-blades $20-55 \mathrm{~cm}$ long, channelled, scabrous and tetragonous or nearly flat near the apex. Inflorescence large, \pm compressed due to surrounding broad bases of bracts, $1.5-3 \mathrm{~cm}$ diam. Involucral bracts: $2-3$ more than three times as long as the inflorescence, $10-30 \mathrm{~cm}$ long; with several to numerous bracts within the inflorescence to twice as long as it; the bases of the outer bracts very broadened, scabrous, brown turning black with age. Spikelets c. $10 \mathrm{~mm}$ long; glumes c. 6, with an erect awn. Anthers $2.5-3.0 \mathrm{~mm}$ long, with an apical appendage c. $1 \mathrm{~mm}$ long. Nut $5.0-6.0 \mathrm{~mm}$ long, $2.5-3.0 \mathrm{~mm}$ diam., yellowish with brown-black spots on upper portion, ovate-oblong; gynophore yellowish, occasionally with brown-black spots, with a very narrow disc. Fig. 3.

Distribution: Widespread in the coastal sandplain heaths and adjoining lateritic scrub heaths and woodlands from south of Geraldton to the Cape Arid region and extending inland to the Stirling Range. As this species is common wherever it occurs, its distribution may be wider than Fig. 5 and the specimen list suggest, given that collectors frequently ignore common plants. This may account for the apparently anomalous occurrence at Narrogin, and also the apparent disjunction between the Scott River Plain and Denmark. Fig. 5.

SPECIMENS EXAMINED: 98.

Selected Specimens: Irwin: Strawberry (c. $75 \mathrm{~km} \mathrm{SE}$. of Geraldton), Ashby 2863, 6.1969 (AD); $29 \mathrm{~km} \mathrm{W.} \mathrm{of} \mathrm{Mingenew} \mathrm{on} \mathrm{Dongara} \mathrm{road,} \mathrm{Wilson} \mathrm{2671,} \mathrm{10.1979} \mathrm{(NSW,} \mathrm{PERTH);} \mathrm{Western}$ Titanium Leases, $8 \mathrm{~km} \mathrm{~S}$. of Eneabba, Griffin 1205, 10.1978 (PERTH); $6 \mathrm{~km} \mathrm{~W}$. of Brand Highway on Cervantes road, Badgingarra National Park, Wilson 2702, 10.1979 (NSW, PERTH). Darling: Drummond: Nilgen road E. of Lancelin, Hnatiuk 770030, 6.1977 (PERTH); Parkerville, Coveny 
8059, 9.1976 (K, NSW, P, PERTH); Wungong Gorge, near Armadale, Blake 18014, 8.1947 BRI, NSW, PERTH); Swan R, Drummond 893 (E, MEL, P); Pinjarrah, Price, 10.1872 (MEL); Waterloo, 50 miles [80 km] S. of Perth, Turvey $N S W 91161,9.1965$ (NSW); Swan R, in arenosis sylvae ad portum Leschenault, Preiss 1807, 11.1839 (MEL, P), 1843 (P); Gales Road, Ambergate, Wilson 3057, 10.1979 (NSW). Dale: $2 \mathrm{~km}$ S. of Mogumber on Wannamal road, Wilson 2722, 10.1979 (NSW, PERTH); $8 \mathrm{~km} \mathrm{NE.} \mathrm{from} \mathrm{Midland} \mathrm{on} \mathrm{Toodyay} \mathrm{road,} \mathrm{Whaite} \mathrm{4106,} \mathrm{9.1976}$ (NSW); Mundaring, Helms, 9.1898 (PERTH). Warren: $5 \frac{1}{2} \mathrm{~km}$ along Fishers Road, E. of Kudardup, Wilson 3052, 10.1979 (NSW); McGregor Road, 8 km S. of Brockman Highway, Scott R Plain, Wilson 3029, 10.1979 (NSW); Hay R., Denmark, Beard 7749, 10.1975 (NSW); Torbay, Sheath NSW 75117, 1.1903 (NSW). Menzies: Lowden, Koch 1406 p.p., 12.1913 (BRI, NSW 22517); Ironstone Ranges 20 miles [32 km] back of Vasse Town, Walcott, 1.1868 (MEL); Boggy Lake, Chtrchill, 12.1957 (PERTH); $7 \mathrm{~km}$ E. of Mt Barker, Wilson 3362, 9.1964 (AD, PERTH); 4 miles [6 km] E. of Kalgan R. on Albany-Mt Manypeaks road, Melville $4427 \&$ Royce, 7.1953 (MEL, NSW, PERTH); Albany, Mueller, 10.1867 (MEL). Avon: Narrogin, Cleland NSW 75120,11.1908 (NSW); $5-6$ miles [8-10 km] NW. of Cranbrook, Green 1736, 10.1957 (PERTH). Eyre: $46 \mathrm{~km} \mathrm{E.} \mathrm{of} \mathrm{Ravensthorpe} \mathrm{on} \mathrm{Esperance} \mathrm{road,} \mathrm{Wilson} \mathrm{2808,} \mathrm{10.1979} \mathrm{(NSW);}$ $10 \mathrm{~km} \mathrm{~S}$. of Mt Baring, Jackson 1310, 10.1968 (AD, PERTH); near Howick Hill, Eichler 19842, 9.1968 (AD, BRI, PERTH) $2 \mathrm{~km} \mathrm{SW}$. of Whartons Campsite, Duke of Orleans Bay, Wilson 2872, 10.1979 (NSW, PERTH); $1 \mathrm{~km}$ W. of Rossiter Bay on road to Lucky Bay, Wilson 2851, 10.1979 (NSW, PERTH), below West Mt Barren, 60 miles [97 km] ESE. of Ongerup, Aplin, Lethbridge \& Coveny 3309, 9.1970 (NSW, PERTH); $1 \mathrm{~km} \mathrm{W.} \mathrm{of} \mathrm{Bremer} \mathrm{Bay} \mathrm{township} \mathrm{on} \mathrm{Boxwood} \mathrm{Hills} \mathrm{road,}$ Wilson 2918, 10.1979 (NSW); Toolbrunup Peak, Stirling Range National Park, Wilson 2988, 10.1979 (NSW); $7 \mathrm{~km} \mathrm{NW}$. of Cape Riche on Wellstead road, Wilson 2948, 10.1979 (NSW, PERTH).

\section{ACKNOWLEDGEMENTS}

To the Directors of the following herbaria for sending specimens on loan or making facilities available to me whilst visiting their institution: AD, B, BM, BRI, E, K, LD, MEL, P, PERTH; also to Dr R. Hnatiuk and Mr K. Newbey, who sent collections for study.

To Mr D. Mackay for drawing figs 1-4.

To Dr P. Lassen and Dr B. Nordenstam for information on Preiss specimens in LD.

\section{REFERENCES}

Beard, J. S. (1980). A new phytogeographic map of Western Australia. Western Austral. Herb. Res. Notes 3: 37-58.

Bentham, G. (1878). 'Flora Australiensis'. (Lovell Reeve \& Co.: London.) Vol. 7.

Brown, R. (1810). 'Prodromus Florae Novae Hollandiae.' (Taylor: London.)

Clarke, C. B. (1908). New genera and species of Cyperaceae. Bull. Misc. Inform. Add. Ser. 8.

George, A. S., Hopkins, A. J. M. and Marchant, N. G. (1979). The heathlands of Western Australia. In Specht, R.L. (Ed.), 'Ecosystems of the world 9A. Heathlands and related shrublands.' (Elsevier: Amsterdam/Oxford/New York.) Pp. 211-230.

Koyama, T. (1961). Classification of the family Cyperaceae (1). J. Fac. Sci. Univ. Tokyo, Sect. 3, Bot. 8: 37-148.

Kükenthal, G. (1939). Vorarbeiten zu einer Monographie der Rhynchosporoideae 7. Repert. Spec. Nov. Regni Veg. 47: 209-216.

Kükenthal, G. (1940). Vorarbeiten zu einer Monographie der Rhynchosporoideae 8. Repert. Spec. Nov. Regni Veg. 48: 49-72.

Metcalfe, C. R. (1971). 'Anatomy of the Monocotyledons. V. Cyperaceae.' (Clarendon Press: Oxford.)

Nees von Esenbeck, C. G. D. (1846). Cyperaceae. In Lehmann, J. G. C. (Ed.), 'Plantae Preissianae.' (Hamburg.) Vol 2, pp. 72-94. 
Nordenstam, B. (1980). The herbaria of Lehmann and Sonder in Stockholm, with special reference to the Ecklon and Zeyher collection. Taxon 29: 279-291.

Pfeiffer, H. (1927). Oreobolus R. Br., eine merkwürdige Cyperaceengattung. Repert. Spec. Nov. Regni Veg. 23: 339-352.

Steudel, E. G. (1854-55). ' 'Synopsis Plantarum Glumacearum.' (Stuttgart.) Vol. 2.

Van der Veken, P. (1965). Contribution à l'Embryographie Systematique des Cyperaceae-Cyperoideae. Bull. Jard. Bot. État 35: 285-354.

Vanhecke, L. (1974). Embryography of some genera of the Cladiinae and the Gahniinae (Cyperaceae) with additional notes on their fruit anatomy. Bull. Jard. Bot. Etat. 44: 367-400.

Verbelen, J. P. (1970). Systematische Embryografie van de CyperaceaeRhynchosporineae. Dodonaea 38: 151-166.

Manuscript received $24,10.1980$. 